\title{
Construction of Social Media Messages and Follower Reactions
}

\author{
A Anditha Sari ${ }^{1}$; Ratna Susanti ${ }^{2}$ \\ ${ }^{1}$ anditha@poltekindonusa.ac.id ${ }^{1}$, ratnasusanti19@poltekindonusa.ac.id ${ }^{2}$ \\ Politeknik Indonusa Surakarta, Surakarta, Indonesia ${ }^{1}$, Politeknik Indonusa Surakarta, Surakarta, \\ Indonesia $^{2}$
}

\begin{abstract}
Grebeg Sudiro celebration is a celebration of the renewal and acculturation of Chinese culture and Javanese culture which is held in "gede" market Area, Surakarta City. As a tradition, this celebration is held every year and is a cultural tour that is awaited by the people of Solo and surrounding cities. The aim of this research is to explore the construction message and follower's reaction during of Grebeg Sudiro celebrations on Instagram especially from the @ visitsurakarta and @ kotasolo_fp as business accounts. In this qualitative descriptive study the method (1) observation in 2 Instagram accounts, (2) recording messages and communication dialogs between the admin and his followers, and (3) message construction. Implications of the results of the study, messages compiled by the Instagram account admin apply persuasive communication to achieve one or three attitudes at once from followers. The initial effect is cognitive, conative and affective outcomes from followers.
\end{abstract}

Keywords: Message, social media,follower

\section{Introduction}

Grebeg Sudiro celebration is a renewal celebration of the Buk Teko tradition. Buk Teko derived from the word "Buk" in Javanese means a cement seat on the edge of a bridge or in front of a house, while the word "Teko" is a teapot, a place for tea) is a thanksgiving tradition before the Chinese New Year. Reporting from [1] this celebration has been celebrated since Sampeyan Dalem Ingkang Sinuhun Kanjeng Susuhunan Paku Buwono X (1893-1939). The cultural event "Grebeg Sudiro" has a long history in the events of Mataram Kingdom. Acculturation of past event with the displacement of Chinese communities around the Surakarta area which is spread in the Ketandan area in front of the Gedhe, Balong, Mijen, Kepanjen, Samaan, Sudiroprajan, and Limolasan Markets. One of the Chinese communities is in a lower class economy area which makes it easier for this community to interact with Javanese people. It is community of balong that has been finally able to realize harmonious interaction making intermarriage occurs.

This years's event Grebeg Sudiro began on January 15, 2020, with a potential bazaar in "Gedhe" market area and it ends with Chinese New Year's Eve on January 24, 2020. During the series of Grebeg Sudiro celebrations, interesting phenomena can be seen through Instagram social media. The account of @ visitsurakarta and @kotasolo_fp on Instagram post about the agenda and social messages that occur during the Grebeg Sudiro celebration in 'gedhe" market area. From various posts or messages delivered by the account administrator it turns out to be able to bring up responses or actions from followers. 
Social media can become a bridge between humans and the outside world. Various types of events present on social media with a variety of communities and interests. In the use of social media [2], it can observe the health and well-being, the economic behavior of its users, the relationship between online social network ownership and compulsive disorder, and online consumer purchase intentions. It can also analyze their friendship on social networks and integrate social networks and theories of behavior or other planned activities. In the article[3], social media make it easy to share word by combining photos and videos. With its simplicity, social media becomes indispensable and as a powerful tool for communicators to attract the attention of the audience. Instagram is an image /video sharing social media application where users take pictures, post and share images online instantly. Instagram was able to reach more than 500 million users in 2016[4].

Writing words as a caption in social media cannot be separated from language as a communication component. Language has a role that can influence society from various social circles. With this view, discourse sees that language is always involved in power relations, especially in subjects' formation, and multiple representation act in society. Seeing the urgency of using language in this study, the appropriate analytical technique used to find out the concept and persuasive meaning of the message is the analysis of critical discourse. The critical discourse analysis model has each version, but there are essential characteristics of critical discourse analysis that are interrelated namely action, context, historical, power, and ideology. From various versions of the critical discourse analysis model, Teun A.Van Djik's method, according to the researchers can reveal the meaning behind the production of texts posted on Instagram. The Teun Van Djik Method [5] explained a text or discourse having a connection between the reason for producing a message as intended by the communicator. In this study, the researcher aims to identify the topic of message construction formed in the context of Grebeg Sudiro's celebration which is interesting for followers and how the construction of the message can elicit reactions from followers.

\section{Literature review}

\subsection{Language Social media}

Language in social media is called by crystal with Netspeak[6].The term speaks not only leads to the meaning of speaking but also to writing (listening and reading). Net refers to the media used to communicate. Another phenomenon in the use of language in social media [7] is the use of media images or illustrations to represent the ideas and feelings of communicators. The use of images or illustrations can be represented by emoticons, stickers, and memes. Emoticons, stickers, and memes can represent the use of images or illustrations. Emoticons and stickers are the same in representing feelings of sadness, happiness, crying, etc. Another illustration is the meme series of illustrated stories that are designed based on the latest public opinion so that readers will also laugh. 


\subsection{Context}

Writing captions in social media remains based on the context created by the communicator. According to Cummings [6], the context in the background is why the production of utterances, which include social, linguistic, and epistemic factors. Another opinion was expressed by Eriyanto [8] the context in a critical discourse consists of the setting, situation, event, and conditions. The context in communication examines matters related to who is communicating with whom and why, what types of audiences and situations, through what mediums, how are the different types of communication and relationship development for each party. It can be concluded that the context as something outside the text, which contains the meaning and purpose, is the background of the occurrence of someone's speech to others.

\subsection{Persuasive Communication}

The application of persuasive communication can be done by making messages that are interesting for the communicant to focus on, which changes or strengthens the communicant's attitude towards the message conveyed by the communicator[9]. The persuasive communication process can be applied in social media.[10] it is done by (1) showing data and facts as decisive evidence to invite (2) creating phenomena that are trending for the communicant (3) posting material in the form of humor or fantasy to be more easily remembered by the communicant because it has a positive emotional effect and (4) choosing words that are easily recognized by the communicant.The results of persuasive communication exposure to the communicant experience two levels. The first level is the change in belief and attitude. The second level of communicant takes action as desired by the communicator[11].

Explained in more depth[12] that persuasive communication is designed as a component of understanding, knowledge assessment, and communicant trust. In conclusion, persuasive communication can achieve the effect in the realm of (1) cognitive, understanding and communicant knowledge of the message conveyed, (2) affective, eliciting emotional communicants to the message conveyed and (3) Conative, the reaction of attitudes that are manifested in action.

\subsection{Instagram}

Instagram is one of the social media sharing pictures/videos where users take pictures, post and share images online instantly. Instagram was able to reach more than 500 million users in 2016 (Lee \& Chau, 2018). An important part of delivering messages on Instagram is images and captions. A caption is a range of text usually placed above or below the image or table to explain or describe what is uploaded, [13]. Caption on Instagram is a transformation of spoken language into written language that contains information on activities, news, opinions, brainstorming, business, and so on. Another advantage of Instagram, users also have followers who can comment on each other or respond to the latest posts from Instagram users. 


\section{Research methods}

The study stages consisted of three stages, namely the stage of data collection, the stage of data classification, and the stage of data analysis. The analysis used by researchers is the analysis of discourse of Teun Van. A.Djik. Through the analysis of discourse Teun A. Van Dijk[5] reveals a context behind the text presented by describing a description of the classification of the text. A discourse or text must be seen related to the production of the text so that we can know the construction of the text. The essence of Van Dijk's analysis is to combine the three dimensions of discourse (text, social cognition and social context) into one analysis unit. In the dimensions of the text under study is how the structure of the text and discourse strategies are used to emphasize a particular theme. This research's object is the captions of the celebration of Grebeg Sudiro on @ visitsurakarta and @ Kotasolo_fp Instagram accounts which were posted between 10 January-28 February 2020.

\section{Results and discussion}

\subsection{Profile of social media accounts}

The researcher choose some accounts that have an agenda or activity in Solo. Researchers observed that there were only two accounts constructing messages in the theme of the Grebeg Sudiro celebration between January 10 and February 28, 2020 namely @ visitsurakarta and @kotasolo_fp. The profile of each account is as follows. (1) @ visitsurakarta is an Instagram account that appeared in February 2016. This account is a business account that applies the paid promote pattern and forms of cooperation for followers who want to post on Instagram. This account with 68 thousand followers places more emphasis on solo agenda content, product advertisements and Friday night horror content. (2) kotasolo_fp account has a tagline as a Community and cultural website. The account that first appeared in May 2013 already has 54 thousand followers. This account has content according to its tagline regarding art and cultural events in the city of Solo.

\subsection{Message construction and Reaction of followers}

From this one thematic, it can be obtained some topic such as (1) lantern lamps in Gede Market area are not yet lit, (2) inauguration of the ornamental boat and mural tours, (3) vandalism in "gedhe" marketarea (4) translate rash in the "gede" market area, 5) Invitation to visit Gede market to see lanterns, 6) sharing to others, and 7) followers' responses to call for shares with others. In making captions, admins occasionally use Javanese. In this article, the researchers translate them in English without reducing the meaning to make it easier for readers to understand.

Researchers in the discussion only display two post views in each account. For the rest, researchers rewrite messages written by the account admin in english. The first topic in the form of "gede" market lanterns are not yet turned on. 


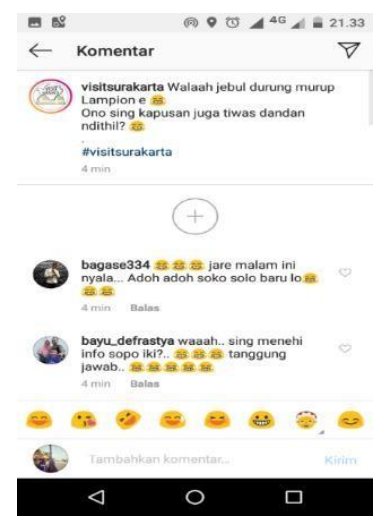

Fig 1. The display of picture at @ visitsurakarta Instagram account telling about lanterns on Gede Market are not yet on

The first topic of the lantern lamps are not yet tuned on which is posted on the @ visitsurakarta account it is written a caption: "wow, apparently the light isn't on yet. Lied to me, already looking neat!" judging by the superstructure of this story caption sub-element, it was made because of a notice in a previous post that the lantern lamp experiment was on January 13, 2020. Viewed from the microstructure, the admin also intends to inform his followers so they are not fooled like the admin. The post gets 1,080 likes and 60 comments, like followers @ bagase334 comment they said tonight lights up, coming away from Solo Baru." @ rizqta18 said 'I was also fooled, min. Evidently not yet lit.' @ dayang.susilo said "luckily not there, min"Many followers' responses as a form of conveying a sense of disappointment. followers also respond by conveying information such as @ nang_taufan said "don't you know ... this night was just an experiment. lights on again on January 15 ,

The second topic is post Opening of the inauguration of ornamental boat and mural tours at @ visitsurakarta. In this post, a caption in this post "On January 14, 2020 yesterday the Mayor of the city FX.Rudyatmo officially opened the ornamental boat tour as the start of the Grebegsudiro 2020. And starting on January 15-25, 2020 Boat tours will open from 18.0022.00. by paying $10000 /$ person you can enjoy the beautiful lanterns on the boat that goes along the "Pepe" River. What are you waiting for! Invite your friends / family / boyfriend to come here!" This caption writing effect is able to generate quite a number of likes from 2,666 followers and 4 comments on the @ visitsurakarta account and on the @ kotasolo_fp account at like 333 followers. Reaction comments that appear @ tomi.agfisaid"which entry, min? @ ronidr tagged two of his friends@Ranggaprwraa and @ aris.awn with the comment "solo like chinese taste" and @umrianii who also tagged his friend @ nandaartu with the comment "great". Little response from followers is seen from the micro semantic sub structure, because the admin is considered to have given clear information about ornamental boat and mural tours. The affirmative language style used also helps followers understand the message conveyed.

The third topic is "Acts of vandalism in "Gede"market area". The admin shows a picture of a wall clock monument in the "gedhe" market that has been scribbled. The admin added the caption "very resentful of people who scribble on public places like this. Whose deeds are these? Not quality ". This post is in the @ visitsurakarta account which gets 833 likes and 60 comments. On the @ kotasolo_fp account, they received 330 likes, 39 comments. This 
post raises the response of negative feelings from followers. Some comments from @visitsurakarta followers @fandy_Ifc said, "If i see what happened, can I hit it, min?" @ habryandinisaid "has hands sewn to keep quiet !"or @ kumalasari_93 said "Have you reported the authorities, min?" The followers of Kotasolo_fp also make similar reactions like @ tiraraharjo said, "usually writing inscriptions like these primitive people who lived millions of years ago. This behavior still exists today"Then @ febryan_ardy said, "If caught, asked to stand at the gede market clock pillar with the words" please scribble on my body. "People can cross as much as possible. Visible negative responses appear because in writing caption, admin in a superstructure also raises resentment with sarcasm. Another thing that provokes followers' emotions is the story that gede market watch monument is one of the public facilities that has become a cultural heritage in the city of Solo.

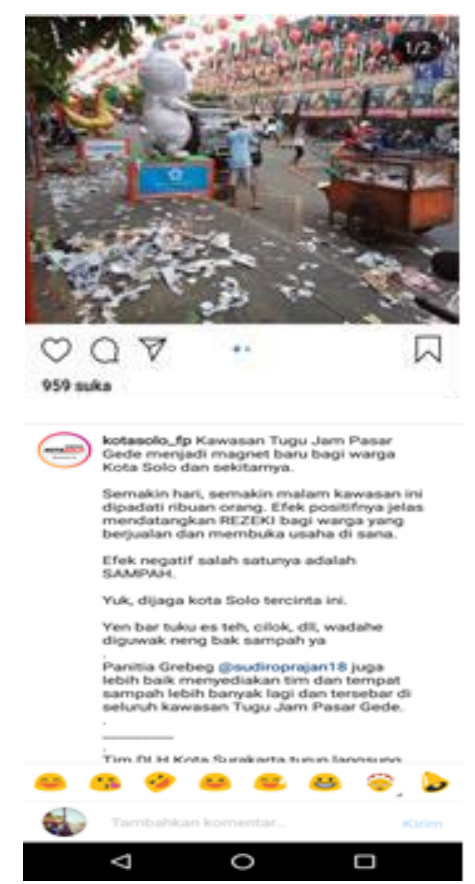

Fig 2. The display of picture telling about garbage in Gede market area

The fourth topic is a post "Trash in the big market area" in the @ visitsurakarta account. Visible pictures of janitors cleaning garbage scattered around the big market area with a caption "Gedhe market clock monument area is a new magnet for the citizens of the city of Solo and surroundings. Day by day, the night the region is filled with thousands of people. The positive effects clearly bring MONEY to business sellers there. One of the negative effects is GARBAGE. Come on, guarded by this beloved solo city. After buying tea, peek, etc. Remove the plastic in the trash, please. The @Grebegsudiroprajan18 committee is better to provide more garbage teams and bins in Gede market clock monument area. DLH team The Surakarta 
City descended directly to respond to complaints from the public regarding the cleanliness conditions in the area of the sudiro / Imlek grebeg 2020 event." In writing the caption, the admin uses coherence to come up with a comparison that with the bazaar there are positive effects and negative effects provide understanding to the followers. Stylistically, the admin writes using a persuasive style. This style is easy to use to invite followers to carry out their appeal.

This post received responses like 959 followers and 39 comments. This post was responded directly by the committee account @ sudiroprajan18 who said, "thank you for the advice, min". The comments of followers on the post also vary from suggestions, responses to criticism, satire, and also praise. Suggestion response delivered by @ sudisaputro account who said,"less visible trash bin, better to be given a trash can, just a suggestion"A compliment response comes from the @ obetonic account said"always healthy for all janitors . God always bless."Criticism also arises from @inkavirdhaniasaid"it's better not to have an event if there's a lot of garbage."The satirical response conveyed by @ kamil-toelsaid "is one example of a picture of citizens in developing countries."

The fifth topic is posting an invitation to visit followers to the big market. Post is equipped with a series of lantern lamps. Admin added the caption "Sunday night is bright, come here at lantern gede market. Take a girlfriend or something else ... Don't forget to return home"reviewed from the semantic admin wrote a detailed condition of the sunny Saturday night weather with the aim of followers interested in visiting lanterns. Stylistically the use of admin language style uses discernment. This posting on the @ visitsurakarta account received 1,365 likes from followers and 51 comments.A small number of followers responded by conveying information that the weather in other regions around Solo was raining. Other followers expressed their reluctance to come because they saw many visitors at the event.

The sixth topic, the theme "share with others" in a post on @ visitsurakarta account. The caption "Info by netizen, this old man usually sells at UNS but last night met him at Gede market Lantern. The ones who play, take selfies, eat snacks, take a boat ... You can also buy this old man's toy. Maybe the toy is meaningless to us, but the money from the sale must mean it for this old man."This post received 2,348 followers likes and 33 comments. Followers respond with a variety of positive attitudes and emotions.Followers responded by buying things like the @dianprita_anjarnako account said"The plane that made by the old man was bought yesterday." Account @ shopalia_hijab "The old man is often at the intersection of the panggung area ... praise God, have bought several times."Other comments from followers convey information about the existence of these parents in addition to the big market lanterns.This post also got a reaction from the youth group a few days later by buying the whole sale and selling it again.

In a semantic review, this post has an admin background getting information from netizens who recognize the toy seller and feel the need to share. The goal is to inform and invite followers to help by buying their wares. In order to achieve this, the admin applies a comparison coherence "the toy does not mean to us, but the money from the sale must mean for this old man." "Our" pronoun syntactically refers to the admin and its followers. "Our" pronoun is use so that followers also feel the call actions.

The posting "sharing with others" was responded by netizens with the caption "Hello admin, thank you for your information, me and the team can meet the warrior figure that we 
are looking for. Tonight we are buying everything up and we are selling 5 thousand and this 5 thousands money will be donated to the Lantern Orphanage.A post responded positively by getting likes 1,922 and 15 comments. The comments made in the form of expressions of pride such as the @ rika-jazz said "are extraordinary, young people are now socially high, the parents are in demand."a thank you was conveyed by @ novitaasri05 said"thank you min, thank you young people ... who have bought up old man toys."Other followers also gave comments in the form of prayers for the admin, youth and followers to get blessed.

The account admin of @ visitsurakarta and @kotasolo_fp as communicators can utilize one theme of Grebeg Sudiro "As a message construction to deliver existing social problems. The choice of topics such as vandalism, rubbish, and caring for others turned out to be a stillimportant topic delivered to build public awareness, The awareness of not damaging public facilities, the consciousness to protect the environment by taking out the trash and putting in its place, and the awareness of sharing with others. This post also received a positive reaction to the number of likes and comments from followers.

Building message construction in each of their posts, adminsitrator @ visitsurakarta and @ kotasolo_fp always use the appropriate image as strong evidence and write detailed captions. Admin accounts @ visitsurakarta and @kotasolo_fp are analyzed stylistically in their posts using the style of affirmation and comparison because both styles are considered more persuasive. This is as stated [10] that in forming persuasive communication can be done by showing data and facts as strong evidence to invite. Other processes in each caption often use satire with Javanese language because it is easier to understand and stick to the minds of followers who are mostly Javanese. The process of achieving a reaction or response from followers is also supported by a factor in establishing dialogue held by the account admin by responding to comments from followers. A dialogical process by giving sufficient attention to responding to important questions or comments is used. This is a means of building relationships with his followers [14].

Seen from the microstructure of the semantic substructure, the admins of both account intend to achieve the response of followers with different levels in writing their caption. The topic "Gede Market lantern lights are not yet lit" and "inauguration of decorative lighting and mural tours" are intended as a delivery of information so that followers become aware of the situation around the big market and the existence of new vehicles. The effect of this message that has an impact on the communicant to know or increase his knowledge is called cognitive effects[15].

In contrast to the topics of "Vandalism in the gede market area" and "Trash in gede market area" the captions are intended as information on environmental conditions in the "Gedhe" market with the activities of the Grebeg Sudiro.But in dialogue followers give many responses by giving rise to dislike, anger and disappointment. Reactions that give rise to expressions such as liking, dislike, or praise are affective effects.One interesting post is the topic "sharing with others". This topic initially received an affective reaction from its followers.But then there was a reaction in the form of actions from some followers who read the post. These followers take action desired by the admin. The follower did the action requested by the admin by buying the old toy seller who was a figure in a previous post.The action that arises from these followers shows the intensity of a good attitude with large or small actions towards an object called the conative effect. 


\section{Conclusion}

The use of Instagram that combines photos or videos together with captions makes it easier for communicators to attract their audience's attention. Account administrators deliver messages through language that is able to influence people from various social circles. This process can be done by making messages that are interesting to the communicant to focus on. The formed understanding finally forms or strengthens the communicant's attitude towards the message conveyed by the communicator..

Admin of account @ visitsurakarta and @kotasolo_fp as communicators can utilize one theme "Grebeg Sudiro" as a message construction to deliver the topic of existing social problems. Admin accompanies posts with pictures as strong evidence and writing detailed captions. The use of local language as a message maker helps the admin in the process of delivering messages to be more attractive to followers. Other factors that lead to followers' attitudes are also supported by dialogue by the account admin by answering questions or responding to comments from followers. The dialogic process easily builds relationships with its followers.

The admins of the accounts @ visitsurakarta and @ kotasolo_fp in writing caption seen from the microstructure of semantic substructure has the intention of achieving the response of followers with different levels. The submission of posts in the form of information has the effect of cognitive messages for the communicant to know or increase his knowledge. Submission of posts in the form of appeals, criticism and invitations igniting the effect of affective for followers with expressions of dislike, anger and disappointment. The post was also able to provide a conative effect when eliciting reactions from followers in the form of large or small actions on the message conveyed.

\section{References}

[1] Silvia Agmasari, “Grebeg Sudiro, Perpaduan Budaya Tionghoa-Jawa di Solo,” travel kompas, p. https://travel.kompas.com/read/2018/02/06/08160082, 2011.

[2] F. R. Gallo, G. I. Simari, M. V. Martinez, and M. A. Falappa, "Predicting user reactions to Twitter feed content based on personality type and social cues," Futur. Gener. Comput. Syst., 2019.

[3] Y. L. Hwong, C. Oliver, M. Van Kranendonk, C. Sammut, and Y. Seroussi, "What makes you tick? The psychology of social media engagement in space science communication," Comput. Human Behav., vol. 68, pp. 480-492, 2017.

[4] C. Lee and D. Chau, "Language as pride, love, and hate: Archiving emotions through multilingual Instagram hashtags," Discourse, Context Media, vol. 22, no. June, pp. 21-29, 2018.

[5] M. R. Y. Firdaus, "Analisis Dikursus Madura Dalam Akun Instagram @ExploreMadura," J. Ilmu Komun., vol. 2, no. 1, 2019. 
[6] N. L. Diasa, "Penyimpangan Prinsip Kesantuan Pengikut ( Followers ) Dalam Wacana Instagram," Univ. Tadulako, vol. 3, no. 4, pp. 1-13, 2018.

[7] F. G. Junus, "Variasi Bahasa dalam Sosial Media : Sebuah Konstruksi Identitas," no. November 2015, 2020.

[8] G. Maghvira, "Critical Discourse Analysis At Tempo.Co on the News About the Death of Taruna Stip Jakarta,” The Mesenger, vol. 9, no. April, pp. 120-130, 2017.

[9] De Vito, Komunikasi Antarmanusia, 5th ed. Jakarta: Karisma Publishing Group, 2011.

[10] Primadhany Kartana Putri, "Pendekatan Persuasif Pada Riset Komunikasi Pemasaran: Iklan Melibatkan Penciptaan dan Penerimaan Pesan Komunikasi Persuasif Mengubah Perilaku Pembelian,” The Mesenger, vol. VIII, no. 1, pp. 1-16, 2016.

[11] M. \& Riyanto, Komunikasi Islami I (Perspektif Itegrasi-Interkoneksi). Yogyakarta: Galuh Patria, 2012.

[12] F. Fitriansyah, "Efek Komunikasi Massa Pada Khalayak (Studi Deskriptif Penggunaan Media Sosial dalam Membentuk Perilaku Remaja)," Cakrawala, vol. 18, no. 2, pp. 171$178,2018$.

[13] F. Poecze, C. Ebster, and C. Strauss, "Social media metrics and sentiment analysis to evaluate the effectiveness of social media posts," Procedia Comput. Sci., vol. 130, pp. 660-666, 2018.

[14] Y. Wang and Y. Yang, Dialogic communication on social media: How organizations use Twitter to build dialogic relationships with their publics, vol. 104. Elsevier B.V., 2020.

[15] L. R. Sari, P. I. Komunikasi, U. Kristen, P. Surabaya, I. Media, and T. B. Shop, "SIKAP KONSUMEN THE BODY SHOP ® SURABAYA TERHADAP PESAN DALAM INSTORE MEDIA BEAUTY WITH HEART," 2011. 